\title{
Banks Dividend Policy and Investment Decision as Determinants of Financing Decision: Evidence from Pakistan
}

\author{
Safdar Husain Tahir ${ }^{*}$, Muhammad Rizwan Ullah'1, Sajid Mahmood ${ }^{2}$ \\ ${ }^{1}$ Department of Banking and Finance, Government College University, Faisalabad, Pakistan \\ ${ }^{2}$ School of Management Sciences, Quaid-i-Azam University, Islamabad, Pakistan \\ Email: safdartahir@gmail.com, rizwan muhammad32@yahoo.com, sajidmahmood26@gmail.com
}

Received 4 April 2015; accepted 24 May 2015; published 27 May 2015

Copyright (C) 2015 by authors and Scientific Research Publishing Inc.

This work is licensed under the Creative Commons Attribution International License (CC BY). http://creativecommons.org/licenses/by/4.0/

(c) (i)

\begin{abstract}
This study investigates empirically the effect of dividend policy and investment decision on financing decision. To obtain the objectives, the data required, ranging from 2004 to 2013, were collected from the financial statements of all the banking firms listed in Karachi Stock exchange. Investment opportunity and actual investment were used as proxies of investment decision. Profitability and firm size were used as control variables. Multiple regression models were used to estimate the variables of interest. It was concluded that investment opportunity had significant effect on financing decision; however, the effects had no particular pattern. Furthermore, actual investment and dividend policy had no impact on financing decision.
\end{abstract}

\section{Keywords}

Banking Sector, Dividend Policy, Financing Decision, Investment Decision, Multiple Regression Model

\section{Introduction}

The leverage irrelevant proposition has been widely discussed in finance literature. Production decision is administrated exclusively by an objective standard with no regard to subjective preferences of individual that go into their expenditure (consumption) decisions in the given complete and perfect capital market (Copeland, Weston, Shastri, \& Education) [1], Fisher separation theorem. This contention is consistent with Williams who has observed firstly the financial policy irrelevant proposition in 1938 (Chen) [2]. The study of Modigliani \& Miller [3]

How to cite this paper: Tahir, S.H., Ullah, M.R. and Mahmood, S. (2015) Banks Dividend Policy and Investment Decision as Determinants of Financing Decision: Evidence from Pakistan. American Journal of Industrial and Business Management, 5, 311-323. http://dx.doi.org/10.4236/ajibm.2015.55032 
also supports the financing irrelevant proposition. Miller [4], DeAngelo \& Masulis [5] have also been supported the financing irrelevant proposition.

Managers are having better information than the outside investors in the real world, which is known as asymmetry information (Brigham et al.) [6]. Asymmetry information is a cause of conflicting investor preferences and harmony will not acquire even between the final shareholders in incomplete market (Taggart) [7]. Asymmetry information involves different theories which support financial decision relevance proposal, just like balancing theory (DeAngelo \& Masulis) [8], (Gardner \& Trzcinka) [9], (Bayless \& Diltz) [10], agency theory (Jensen \& Meckling) [11], pecking order theory (Myers) [12], (Myers \& Majluf) [13], trade off theory (Brigham et al.) [14], or signaling theory (Megginson, Megginson, \& Meggison) [15].

The mix result among the different financing decision relevancy theories is shown by the empirical evidence. A few studies support the balancing theory, like (Crutchley \& Hansen) [16], (Kale, Noe, \& Ramirez) [17], and (Gardner \& Trzcinka) [9]. Few studies support the pecking order theory, including (Carleton \& Silberman) [18], (Baskin) [19], (Barton, Hill, \& Sundaram) [20], (Bayless \& Diltz) [10], (Adedeji; Shyam-Sunder \& Myers) [21] [22]. Other theories support mixture of both two theories, such as (Jensen, Solberg, \& Zorn) [23] and (Griner \& Gordon) [24] support pecking order theory and agency theory both.

\subsection{Balancing Theory}

Brigham et al. [25] have examined the behavior of managers on the basis of business risk. They have predicted that in less risky conditions firms use more debts and in high risky conditions firms use fewer debts. Thus, in less risky conditions, there should be a positive influence of growth on financing decision, and in high risky conditions, there should be a negative influence of growth on financing decision.

\subsection{Agency Theory}

Jensen and Meckling [11] state that dividend minimizes the free cash flow, it also minimizes the interest conflicts among the principal and agent. Kalay [26] highlights that debt financed dividend can be paid by the stockholders, thereby maximizing the outstanding bonds risk. Harris and Raviv [27] argue that the disciplining device is debt because in case of default creditors will get the option to force the companies to close the business and produce useful information for investors. Easterbrook [28] also argues that for the equity holders the dividends are beneficial because equity holders can force the managers to get new capital. Agency theory predicts that there is a positive impact of dividend on financing decision.

\subsection{Pecking Order Theory}

Myers and Majluf [13] have argued that the use of internal funds is the preference of firms. If there is a need of external funds, managers opt debt financing instead of issuance the new equity. It is supposed that profitability is constant relatively; the theory indicated that there is a positive influence of investments on the financing decision. If firms violate any financing order, it will lead to high investment risk or financial difficulties.

\subsection{Problem Statement}

Analyzing the effect of banks dividend policy and investment decision as a determinant of financing decision in banking sector of Pakistan is the core issue to be addressed. The center of attention of the study will be whether the effect of dividend policy and investment decision is going to define the financing decision or not. The nature of present research gap is quite difficult to understand as the said topic is critically analyzed by various researchers in way of how the dividend policy and investment are going to define the financing decision for a business. In addition to the above problem, the said effect must be analyzed by controlling the effect of firm size and profitability.

\subsection{Objectives of the Study}

- To investigate whether dividend policy and investment decision influence financing decision.

- To attempt to control the effect of firm size and profitability on financing decision. 


\subsection{Organization of the Study}

The rest part of the study is organized as: Section 2 is the review of the literature of the existing relationship among dividend policy, investment decision and financing decision; Section 3 includes the research methodology and development of hypothesis; Section 4 explains the empirical results and discussions; Section 5 consists of conclusion and directions for the future studies.

\section{Review of Literature}

Fisher separation theorem argued that managers of a company made firstly the investment decision and secondly they made financing decision, but both the decisions were independently. However, if it is supposed that asymmetry information exists, the separation cannot be held for the long period of time. To make the investment decision, the behavior of the managers cannot directly observed by the outside investors. Hence, they always try to observe the behavior of managers in other side (financing decision) to access the decision of investment.

Investment decision cannot observe directly. Myers [29] acquaints the term investment opportunity set which means the extent to which the firm value depends on future optional expenditures by the firm. There are a number of proxies in finance literature and accounting to capture Myers' view of investment opportunity set (IOS), just like Gaver and Gaver [30], Smith Jr. and Watts [31]. There are three kinds of these proxies classified by Kallapur and Trombley [32]: investment-based proxies, price-based proxies and variance measures. They have observed that price-based proxies are better than other two proxies of investment opportunity set to be associated to realize growth as benchmark. On the basis of Fisher separation theorem, investment decision effects financing decision but it is supposed that asymmetry information exists.

Wang, Huang, and Wang [33] have explained that as regard to the lifecycle stage of a company, there was a negative impact of dividend on investment. They further observed that inconsistent impact of investment decision on borrowing and borrowing on investment decision at different levels, which means the capital market was imperfect.

Kaaro [34] has demonstrated that the level of risk is the element which causes the effect of investment decision on financing decision. He further explains that in low risky conditions companies use more funds for investment and use low funds in high risky conditions. Balancing theory, pecking order theory and signaling theory explain that dividend policy has a negative effect on financing decision.

Abbott [35] has indicated that there is negative correlation between the dividend policy and subsequent realized growth and a negative correlation between the market debt-to-equity ratios and investment opportunity set movements. Whereas book debt-to-equity ratios have positive correlation with investment opportunity set movements.

Galeotti and Dieci [36] have stated that a firm does not pay dividends before the completion of the time horizon. They further observe that firms practicing a purely accounting system, wants to maximize their retain earnings. While considering random cash flow assumption the situation differs. They also narrate in their model that the rate of dividend can depend on the previous decision.

Berkovitch and Narayanan [37] have narrated that if there is no perfect competition between the financial markets then there is a relationship between the financing decision and the investment decision. If the economic conditions getting better then the percentage of equity financing will be greater with respect to the debt. If the past economics conditions are on average lesser, the portion of equity financing and portion of types of financing will be greater. And the industry projects having low existence rate are highly financed by equity.

\section{Research Gap}

On the basis of Fisher separation theorem, investment decision effects financing decision but it is supposed that asymmetry information exists. Kallapur and Trombley [32] have investigated actual investment or (current) realized growth and future growth both to observe the investment decisions that affect the financing decision. But in above studies, it is not cleared that what is the relationship among dividend policy, investment decision and financing decision. This study will attempt to observe the association between said variables.

\section{Research Methodology}

The data from 2004 to 2010 is used in this study. To calculate the growth of total assets and sales growth, the 
data of period 2003 is also used. The data consists of annual financial reports of all banking firms of Pakistan which are listed in Karachi Stock Exchange.

\subsection{Variables Description}

Three types of variables are used in this study and discussed below.

\subsubsection{Dependent Variable}

Financing decision (financial leverage) is to be considered as dependent variable measured in terms of total debt to total assets ratio. It is computed as:

$$
\mathrm{FL}=\text { Total Debt/Total Assets }
$$

\subsubsection{Independent Variables}

The independent variables are dividend policy and investment decision.

1) Dividend Policy

Dividend policy is measured by dividend yield.

Dividend Yield (DY)

DY is the ratio of dividend per common share to market price per common share at the end of year. The dividend yield depends on the dividend policy of the firm and the market price. Dividend yield is computed as follow:

$$
\text { DY = Dividend per share/Stock price of previous year }
$$

2) Investment Decision

Investment decision includes two variables which are actual investment and investment opportunity.

\section{Actual Investment}

Actual investment is measured as total assets growth and sales growth of banks over a period of time. The formula of growth is as follows.

$$
\begin{aligned}
\text { Total assets growth } & =\left(\mathrm{TA}_{\mathrm{t}}-\mathrm{TA}_{\mathrm{t}-1}\right) / \mathrm{TA}_{\mathrm{t}-1} \\
\text { Sales growth } & =\left(\mathrm{S}_{\mathrm{t}}-\mathrm{S}_{\mathrm{t}-1}\right) / \mathrm{S}_{\mathrm{t}-1}
\end{aligned}
$$

\section{Investment Opportunity}

Investment opportunity is measured by two variables of earnings per share to stock price (EPSSP) and capital intensiveness.

$$
\begin{aligned}
& \text { EPSSP = Earnings per share/Stock price } \\
& \text { Capital intensiveness }=\text { Total equity } / \text { Sales }
\end{aligned}
$$

\subsubsection{Control Variables}

The control variables of the study are following.

1) Firm Size (FS)

It is the size of bank and measured as logarithm of total assets at the end of year. Firm size may influence the financing decision of banks.

2) Return on Assets (ROA)

Return on assets is measured in terms of profit after tax to total assets ratio at the end of financial year. It shows the ability of banks to create profits by utilizing its assets.

$$
\text { ROA = Profit after tax/Total Assets }
$$

\subsection{Development of Hypothesis}

On the basis of existing literature we can develop the following hypotheses:

$\mathrm{H}_{1}$ : There is a relation between dividend policy and financing decision.

$\mathrm{H}_{2}$ : There is an association between investment opportunity and financing decision. 
$\mathrm{H}_{3}$ : There is a linkage between realized growth (actual investment) and financing decision.

\subsection{Model Specification}

In order to test the hypothesis we use multiple regression models on the sample data of firms and following models are developed:

$$
\begin{gathered}
F L_{i t}=\beta 0+\beta 1 D Y_{i t}+\beta 2 T A G_{i t}+\beta 3 S G_{i t}+\beta 4 E P S S P_{i t}+\beta 5 C I_{i t}+e_{i t} \\
F L_{i t}=\beta 0+\beta 1 D Y_{i t}+\beta 2 T A G_{i t}+\beta 3 S G_{i t}+\beta 4 E P S S P_{i t}+\beta 5 C I_{i t}+\beta 6 F S_{i t}+\beta 7 R O A_{i t}+e_{i t} \\
F L_{i t}=\beta 0+\beta 1 D Y_{i t}+\beta 2 T A G_{i t}+\beta 3 S G_{i t}+\beta 4 E P S S P_{i t}+\beta 5 C I_{i t}+\beta 6 F S_{i t}+e_{i t} \\
F L_{i t}=\beta 0+\beta 1 D Y_{i t}+\beta 2 T A G_{i t}+\beta 3 S G_{i t}+\beta 4 E P S S P_{i t}+\beta 5 C I_{i t}+\beta 6 R O A_{i t}+e_{i t}
\end{gathered}
$$

\section{Empirical Results}

The study has explained the outcomes of panel data regression analysis to analyze the impact of dividend policy and investment decision on financing decision of banking firms in this section.

\subsection{Descriptive Statistics}

The descriptive statistics outcomes of annual data from 2004 to 2013 said that the mean value of financial leverage in 2004 was 0.1299 but it decreased in 2005. In 2006 and 2007 the mean value of financial leverage was increased. In 2008 and 2009, there was diminishing growth in financial leverage, it was slightly increased in 2010 and 2011 (11.95 and 14.36), but in 2012 and 2013, there was dramatically diminishing growth. There is one possible explanation with the results. Many banking firms have been lost of their profits during the period of global financial crisis. Global financial crisis showed their effect in the middle of 2007-2008, stock markets had fallen in all over the world and larger institutions had crashed. On the other side, the global financial crisis influenced the livelihood of everyone connected in the world. In 2009 the banking firms started the recovery of their profits. The internal funding reduced due to the lost of profits. Pecking order theory (Myers and Majluf) [13] gives preference of external debt over financing new equity.

The mean value of DY is negative in $2008(-0.0012), 2009(-0.0730)$ and $2010(-0.0288)$. There is declining growth in the DY from the period of 2004 to 2009, and increasing growth in 2010 and 2011 but slightly decrease in 2012 and 2013. The results show that dividend distribution is relatively lower in uncertainty conditions (economic crisis) and relatively higher in certainty conditions (economic normal). The fluctuation in DY is relatively low.

The mean value of TAG and SG is 0.3884 and 0.4804 respectively in 2004. The mean values of TAG and SG are increased in 2005 and decreased in 2006 and the value of TAG and SG increased in 2007, in 2009 and 2010, both the variables are decreased, but increased in 2011. In 2008 and 2012, the mean value of TAG increased but the mean value of SG decreased. In 2013 mean values of both variables are decreased. The variation of TAG and SG is greater. These variables represent the realized growth.

EPSSP's mean value as proxy of investment opportunity is positive in 2004 through 2007, but it is negative in 2008 through 2010. It is also positive in 2011 and 2012 and again negative in 2013.The results report that because of economic crisis, the firms suffer losses, in 2011, the firms start the recovery of the losses and increase the performance. Another possibility of explanation can be based on compensation theory. This theory explains that if there is existence of upper and lower bonus plan, the managers of firms might prefer to opt take a bad in period of 2008, 2009 and 2010 to get high bonus in the period of 2011, 2012 and 2013 (Healy) [38]. The mean value of CI, which is also a proxy of investment opportunity, is higher in 2006 (2.8661) and lower in 2013 (1.0274). The banking firms are more capital intensive in 2004 (2.4556), 2006 (2.8661) and 2007 (2.1199), which means in 2004, 2006, and 2007, banking firms are more capital intensive. The variations in CI are relatively low.

The mean value of ROA is negative in the periods of 2008 through 2010. Because of global financial crisis many banking firms suffer loss. In the period of 2010, many banking firms start recovery, improve the performance and increase the ROA. This means that in the period of financial crisis the performance of firms affect badly. The maximum mean size of banking firms is in 2013 (8.4825) and the minimum in 2006 (7.8536). There 
is increasing growth in the size of banking firms from 2006 to 2013. The FS is slightly decreased in the period of 2006.

\subsection{Regression Analysis}

Table 1 shows the result of regression analysis without controlling variables of FL by using absolute dividend yield. Table 1 reports that the DY has significant negative impact on FL only in the period of 2011 (Coef. = $-0.8646, \mathrm{t}=-3.9024)$. So the dividend policy does not confirm the first hypothesis of the study. TAG significantly negatively influences FL in the period of 2012 (Coef. $=-0.2774, \mathrm{t}=-5.7558$ ) and 2013 (Coef. $=$ $-0.1673, t=-3.1137$ ) at the significance level of 0.01 . Table 1 represents that SG has significant positive effect on FL in the period of 2009 (Coef. $=0.4032, \mathrm{t}=3.2385$ ) and 2013 (Coef. $=0.2159, \mathrm{t}=4.2681$ ) at 0.01 level of significance. EPSSP as a proxy of investment opportunity significantly influences FL in the period of 2011 (Coef. $=0.8972, t=4.2335$ ) at the significance level of 0.01 . The positive influence is showing that there are more investment opportunities in 2011. Table 1 shows that only the CI consistently significantly influences FL in the period of 2008 through 2013. The periods of 2008 to 2013 represent normal (less uncertainty) condition in the economy.

Table 2 reports the regression analysis results with two controlling variables (FS and ROA) of FL by using absolute dividend yield. After controlling the effect of controlling variables of the study, the impact of DY becomes significant in the period of 2007 (Coef. $=-0.7607, \mathrm{t}=-2.1886$ ), 2008 (Coef. $=0.3698, \mathrm{t}=2.4119$ ), 2011 (Coef. $=-0.5595, \mathrm{t}=-2.3513$ ) and 2012 (Coef. $=-0.3087, \mathrm{t}=-2.4185)$ at the significance level of 0.05 . Results indicate that dividend policy, after controlling the effect of controlling variables, inconsistently influences FL. TAG is found to be significant in the period of 2012 (Coef. $=-0.1691, \mathrm{t}=-2.1193$ ) and 2013 (Coef. $=$ $-0.1567, t=-2.6519$ ). EPSSP as a proxy of investment opportunity is significant positive in 2011 and 2012 only. These periods represent economic normal indicating that there are more investment opportunities. CI becomes significant positive in all the years except 2005 after controlling the impact of controlling variables at the level

Table 1. Regression analysis of total debt to total assets using absolute dividend yield (t-value in parenthesis) (Equation: (1)).

\begin{tabular}{|c|c|c|c|c|c|c|c|c|c|c|}
\hline \multirow{3}{*}{ Variable } & \multicolumn{10}{|c|}{ Panel A } \\
\hline & \multicolumn{10}{|c|}{ Regression analysis without controlling variables } \\
\hline & 2004 & 2005 & 2006 & 2007 & 2008 & 2009 & 2010 & 2011 & 2012 & 2013 \\
\hline \multirow[t]{2}{*}{ Constant } & 0.1102 & 0.1865 & $0.1695^{*}$ & 0.1108 & -0.0193 & $-0.0645^{* * *}$ & -0.0227 & -0.0160 & $0.0044^{*}$ & 0.0000 \\
\hline & $(0.7711)$ & $(0.9601)$ & $(1.7592)$ & $(1.0032)$ & $(-1.1276)$ & $(-3.4305)$ & $(-0.7623)$ & $(-0.6346)$ & $(1.7365)$ & $(0.0062)$ \\
\hline \multirow[t]{2}{*}{ DY } & 0.0670 & -0.2015 & -0.3275 & -0.1519 & 0.1661 & -0.3063 & -0.3433 & $-0.8646^{* * *}$ & -0.0836 & 0.0136 \\
\hline & $(0.0672)$ & $(-0.5934)$ & $(-0.8119)$ & $(-0.1027)$ & $(0.7197)$ & $(-1.510)$ & $(-0.9246)$ & $(-3.9024)$ & $(-0.6451)$ & $(0.0812)$ \\
\hline \multirow[t]{2}{*}{ TAG } & 0.0145 & -0.2173 & 0.2501 & -0.2805 & 0.0037 & $-0.4305^{* * *}$ & -0.1157 & 0.0187 & $-0.2774^{* * *}$ & $-0.1673^{* * *}$ \\
\hline & $(0.0289)$ & $(-0.7056)$ & $(0.7507)$ & $(-0.6737)$ & $(0.0443)$ & $(-2.9580)$ & $(-0.7421)$ & $(0.2226)$ & $(-5.7558)$ & $(-3.1137)$ \\
\hline \multirow[t]{2}{*}{ SG } & -0.0394 & 0.0831 & -0.1259 & 0.2447 & -0.1064 & $0.4032^{* * *}$ & -0.0854 & 0.0577 & -0.0044 & $0.2159^{* * *}$ \\
\hline & $(-0.0801)$ & $(0.2423)$ & $(-0.3936)$ & $(0.5933)$ & $(-1.0100)$ & (3.2385) & $(-0.5249)$ & $(0.8408)$ & $(-0.1199)$ & $(4.2681)$ \\
\hline \multirow[t]{2}{*}{ EPSSP } & -0.1587 & -0.1588 & 0.1823 & 0.1347 & -0.2218 & 0.0711 & 0.1635 & $0.8972^{* * * *}$ & 0.0947 & -0.0094 \\
\hline & $(-0.1590)$ & $(-0.4707)$ & $(0.4854)$ & $(0.0905)$ & $(-0.9763)$ & $(0.3473)$ & $(0.4448)$ & $(4.2335)$ & (0.7399) & $(-0.0547)$ \\
\hline \multirow[t]{2}{*}{ CI } & 0.1417 & -0.1581 & 0.2548 & 0.2941 & $0.9874^{* * *}$ & $1.1007^{* * *}$ & $0.8897^{* * *}$ & $0.8657^{* *} *$ & $1.1398^{* * *}$ & $1.0209^{* * *}$ \\
\hline & $(0.3679)$ & $(-0.4380)$ & $(0.7188)$ & $(0.6431)$ & (10.6514) & (11.7316) & (10.7504) & (13.7739) & (34.4702) & (32.3259) \\
\hline $\mathrm{R}^{2}$ & 0.0350 & 0.0730 & 0.2479 & 0.0925 & 0.8874 & 0.9359 & 0.9081 & 0.9746 & 0.9919 & 0.9859 \\
\hline Adjusted $\mathrm{R}^{2}$ & -0.5011 & -0.3133 & 0.0129 & -0.1910 & 0.8542 & 0.9170 & 0.8811 & 0.9671 & 0.9896 & 0.9818 \\
\hline F & 0.0654 & 0.1889 & 1.0548 & 0.3263 & $26.7818^{* * *}$ & $49.6074^{* * *}$ & $33.6097^{* * *}$ & $130.5283^{* * *}$ & $418.4328^{* * *}$ & $237.7983^{* * *}$ \\
\hline
\end{tabular}

Note: ${ }^{*}$ Significant at $0.1 ;{ }^{* * *}$ Significant at $0.05 ;{ }^{* * *}$ Significant at 0.01 . Notes: DY is dividend yield; TAG is total assets growth; SG is sales growth; EPSSP is earning per share to stock price; CI is capital intensiveness 
Table 2. Regression analysis of total debt to total assets using absolute dividend yield (t-value in parenthesis) (Equation: (2)).

\begin{tabular}{|c|c|c|c|c|c|c|c|c|c|c|}
\hline \multirow{3}{*}{ Variable } & \multicolumn{10}{|c|}{ Panel B } \\
\hline & \multicolumn{10}{|c|}{ Regression analysis two all controlling variables } \\
\hline & 2004 & 2005 & 2006 & 2007 & 2008 & 2009 & 2010 & 2011 & 2012 & 2013 \\
\hline \multirow[t]{2}{*}{ Constant } & -0.1338 & 0.0387 & 0.3505 & $0.8270^{* * *}$ & -0.0458 & $-0.6185^{* *}$ & $-0.7674^{* * *}$ & -0.2767 & $0.1035^{* * *}$ & -0.0231 \\
\hline & $(-0.6593)$ & $(0.0753)$ & $(1.0692)$ & $(3.0937)$ & $(-0.3384)$ & $(-2.2248)$ & $(-4.3901)$ & $(-1.4074)$ & $(3.0388)$ & $(-0.4142)$ \\
\hline \multirow[t]{2}{*}{ DY } & 0.0310 & 0.0083 & -0.1822 & $-0.7607^{*} *$ & $0.3698^{* *}$ & -0.3731 & -0.0722 & $-0.5595^{* *}$ & $-0.3087^{* *}$ & 0.1149 \\
\hline & $(0.3005)$ & $(0.0963)$ & $(-1.1812)$ & $(-2.1886)$ & (2.4119) & $(-0.8267)$ & $(-0.2845)$ & $(-2.3513)$ & $(-2.4185)$ & $(0.4448)$ \\
\hline \multirow[t]{2}{*}{ TAG } & -0.0712 & 0.0116 & 0.0642 & -0.0757 & 0.0061 & -0.1783 & -0.0115 & 0.0137 & $-0.1691^{* *}$ & $-0.1567^{* *}$ \\
\hline & $(-1.4404)$ & $(0.0795)$ & (0.6629) & $(-0.7166)$ & (0.1194) & $(-0.8443)$ & $(-0.1260)$ & (0.1992) & $(-2.1193)$ & $(-2.6519)$ \\
\hline \multirow[t]{2}{*}{ SG } & 0.0346 & -0.0309 & 0.0039 & -0.1466 & 0.0518 & 0.2551 & 0.0879 & $0.1241^{*}$ & -0.0450 & 0.1480 \\
\hline & $(0.6300)$ & $(-0.2968)$ & $(0.0381)$ & $(-1.3997)$ & $(0.7233)$ & $(1.5422)$ & $(0.9196)$ & (1.8996) & $(-1.2918)$ & (1.6448) \\
\hline \multirow[t]{2}{*}{ EPSSP } & -0.6300 & 0.0595 & -0.0994 & -0.0638 & 0.1006 & 0.3547 & 0.3230 & $0.6232^{* * * *}$ & $0.3589^{* * *}$ & -0.0631 \\
\hline & $(-0.3289)$ & $(0.7296)$ & $(-0.7570)$ & $(-0.1728)$ & $(0.3950)$ & (0.4969) & (1.1973) & (3.0426) & (2.6943) & $(-0.2645)$ \\
\hline \multirow[t]{2}{*}{ CI } & $0.2990^{* * *}$ & 0.2211 & $0.4371^{* * *}$ & $0.4627^{* * *}$ & $0.7709^{* * *}$ & $1.0561^{* * *}$ & $0.7410^{* * *}$ & $0.8055^{* * *}$ & $1.0993^{* * *}$ & $1.0538^{* * * *}$ \\
\hline & (6.9591) & (1.2747) & (3.3193) & (3.9691) & (9.5417) & (9.7669) & (13.2327) & (12.5762) & (30.5890) & (22.9165) \\
\hline \multirow[t]{2}{*}{ FS } & 0.0909 & -0.0056 & -0.1062 & $-0.2322^{*} *$ & 0.0202 & $0.2270^{*}$ & $0.2326^{* * *}$ & 0.0735 & $-0.0997^{* * *}$ & 0.0295 \\
\hline & (0.9094) & $(-0.0220)$ & $(-0.7216)$ & $(-2.5203)$ & $(0.2630)$ & (1.8230) & (4.0248) & (1.4111) & $(-2.8769)$ & $(0.4255)$ \\
\hline \multirow[t]{2}{*}{ ROA } & $1.0557^{* * *}$ & $1.1238^{* * *}$ & $0.9469^{* * *}$ & $0.9606^{* * *}$ & -0.5862 & -0.3020 & $-0.6737^{* * *}$ & $-0.2863^{* * *}$ & 0.0602 & -0.1033 \\
\hline & (18.0157) & (7.0826) & (9.6106) & (11.5889) & $(-0.5861)$ & $(-0.9045)$ & $(-5.6981)$ & $(-3.0790)$ & (0.8759) & $(-1.1065)$ \\
\hline $\mathrm{R}^{2}$ & 0.9970 & 0.9677 & 0.9561 & 0.9636 & 0.9712 & 0.9538 & 0.9799 & 0.9880 & 0.9959 & 0.9880 \\
\hline Adjusted $\mathrm{R}^{2}$ & 0.9916 & 0.9314 & 0.9232 & 0.9362 & 0.9513 & 0.9218 & 0.9660 & 0.9796 & 0.9930 & 0.9797 \\
\hline $\mathrm{F}$ & $185.3767^{* * * *}$ & $26.6546^{* * * *}$ & $29.0488^{* * * *}$ & $35.2652^{* *} *$ & $48.7496^{* * * *}$ & $29.8049^{* * * *}$ & $70.5420^{* * *}$ & $118.5317^{* * *}$ & $349.7507^{* * *}$ & $118.9112^{* * *}$ \\
\hline
\end{tabular}

Note: ${ }^{*}$ Significant at $0.1 ;{ }^{* *}$ Significant at $0.05:{ }^{* * *}$ Significant at 0.01 . Notes: DY is dividend yield; TAG is total assets growth; SG is sales growth; EPSSP is earning per share to stock price; CI is capital intensiveness; FS is firm size; ROA is return on assets.

of 0.01. Results show that in less uncertainty conditions the banking firms are more capital intensive as the values of $t$ statistics are higher in the period of economic normal. The FS has inconsistent impact on FL. FS is mostly significant in economic normal but insignificant in economic crisis. ROA has significant impact on FL in the period of 2004 through 2007, 2010 and 2011. The variation in coefficient of determination $\left(R^{2}\right)$ is relatively low.

In order to test the analysis of sensitivity of the impact of each controlling variable on the models using dividend yield variable of dividend policy, in each model (equation), each controlling variable is included.

Table 3 interprets the results of regression analysis with FS controlling variable by using dividend yield. This table reports the sensitivity effect of FS controlling variable. The dividend yield is only significant in the period of 2011 (Coef. $=-0.8804, \mathrm{t}=-3.9838$ ) and 2012 (Coef. $=-0.2604, \mathrm{t}=-2.2341$ ) at the significance level of 0.01 and 0.05 respectively. The results are different with the Panel A on Table 1. It suggests that absolute dividend yield is sensitive to FS. Other outcomes are relatively same with Table 1 and Table 2 . The variation in the coefficient of determination $\left(\mathrm{R}^{2}\right)$ is relatively high. In high uncertainty conditions the $\mathrm{R}^{2}$ value is low but high in less uncertainty conditions.

Table 4 reports the results of regression analysis with ROA controlling variable by using absolute dividend yield. This table shows the sensitivity effect of ROA controlling variable. The DY is significant in 2006 (Coef. = $-0.3774, \mathrm{t}=-3.5505), 2008$ (Coef. $=0.3906, \mathrm{t}=3.0969) 2011$ (Coef. $=-0.5141, \mathrm{t}=-1.9844$ ) at the significance level of $0.01,0.01$ and 0.1 respectively. The results are relatively different with Panel A on Table 1. It shows that the absolute DY is also sensitive to ROA. TAG has significant negative impact on FL in 2009, 2012 
Table 3. Regression analysis of total debt to total assets using absolute dividend yield (t-value in Parenthesis) (Equation: (3)).

\begin{tabular}{|c|c|c|c|c|c|c|c|c|c|c|}
\hline \multirow{3}{*}{ Variable } & \multicolumn{10}{|c|}{ Panel A } \\
\hline & \multicolumn{10}{|c|}{ Regression analysis with FS controlling variable } \\
\hline & 2004 & 2005 & 2006 & 2007 & 2008 & 2009 & 2010 & 2011 & 2012 & 2013 \\
\hline \multirow[t]{2}{*}{ Constant } & $2.8803^{* * *}$ & $2.8536^{* * *}$ & $2.2135^{* * *}$ & $2.6853^{* * *}$ & -0.1257 & $-0.6211^{* *}$ & $-0.5982^{* *}$ & -0.2527 & $0.0874^{* * *}$ & 0.0215 \\
\hline & $(4.4427)$ & $(4.3634)$ & (3.3622) & $(3.8534)$ & $(-0.5554)$ & $(-2.4530)$ & $(-2.1933)$ & $(-1.1434)$ & (3.4448) & $(0.5858)$ \\
\hline \multirow[t]{2}{*}{ DY } & 0.6957 & 0.1691 & 0.1630 & -0.4753 & 0.1144 & -0.0481 & -0.2716 & $-0.8804^{* * *}$ & $-0.2604^{* *}$ & 0.0612 \\
\hline & (1.1638) & $(0.7091)$ & $(0.4526)$ & $(-0.4300)$ & (0.4389) & $(-0.2214)$ & $(-0.7994)$ & $(-3.9838)$ & $(-2.2341)$ & $(0.3240)$ \\
\hline \multirow[t]{2}{*}{ TAG } & -0.5444 & 0.2149 & 0.0638 & -0.0187 & 0.0170 & -0.1490 & -0.1879 & 0.0271 & $-0.2303^{* * *}$ & $-0.1704^{* * *}$ \\
\hline & $(-1.7064)$ & $(0.9510)$ & $(0.2325)$ & $(-0.0587)$ & $(0.1875)$ & $(-0.8126)$ & $(-1.2869)$ & $(0.3235)$ & $(-5.6124)$ & $(-3.0955)$ \\
\hline \multirow[t]{2}{*}{ SG } & -0.1566 & -0.2275 & 0.0367 & -0.1139 & -0.1008 & $0.2428^{*}$ & 0.0532 & 0.1032 & -0.0234 & $0.2275^{* * *}$ \\
\hline & $(-0.5454)$ & $(-0.9654)$ & (0.1399) & $(-0.3540)$ & $(-0.9290)$ & (1.8128) & $(0.3281)$ & (1.2858) & $(-0.7775)$ & $(4.1204)$ \\
\hline \multirow[t]{2}{*}{ EPSSP } & -0.5405 & 0.0171 & 0.2619 & 0.7386 & -0.1887 & -0.2185 & 0.0606 & $0.8900^{* * *}$ & $0.2943^{* *}$ & -0.0462 \\
\hline & $(-0.9197)$ & $(0.0765)$ & $(0.8645)$ & (0.6598) & $(-0.7768)$ & $(-0.9636)$ & (0.1791) & $(4.2171)$ & (2.4783) & $(-0.2495)$ \\
\hline \multirow[t]{2}{*}{ CI } & 0.0550 & $-0.4590^{*}$ & -0.0846 & -0.0030 & $1.0174^{* * *}$ & $1.0229^{* * *}$ & $0.9267^{* * *}$ & $0.9032^{* * *}$ & $1.1062^{* * *}$ & $1.0139^{* * * *}$ \\
\hline & $(0.2445)$ & $(-1.8655)$ & $(-0.2774)$ & $(-0.0085)$ & (8.8986) & (11.1436) & (11.9788) & (12.6200) & (39.1196) & (29.5422) \\
\hline \multirow[t]{2}{*}{ FS } & $-1.1516^{* * *}$ & $-1.1085^{* * *}$ & $-0.9090^{* * *}$ & $-0.8748^{* * *}$ & 0.0592 & $0.2390^{* *}$ & $0.1787^{* *}$ & 0.0593 & $-0.0781^{* * *}$ & -0.0232 \\
\hline & $(-4.3083)$ & $(-4.1568)$ & $(-3.1263)$ & $(-3.7204)$ & $(0.4715)$ & (2.2029) & (2.1206) & (1.0781) & $(-3.2792)$ & $(-0.5882)$ \\
\hline $\mathrm{R}^{2}$ & 0.7094 & 0.6394 & 0.5446 & 0.5281 & 0.8889 & 0.9508 & 0.9283 & 0.9763 & 0.9952 & 0.9862 \\
\hline Adjusted $\mathrm{R}^{2}$ & 0.4914 & 0.4427 & 0.3625 & 0.3393 & 0.8472 & 0.9323 & 0.9014 & 0.9675 & 0.9934 & 0.9810 \\
\hline F & $3.2543^{*}$ & $3.2508^{*}$ & 2.9900 & 2.7972 & $21.3343^{* * *}$ & $51.5183^{* * *}$ & $34.5195^{* * *}$ & $110.0062^{* * * *}$ & $550.5495^{* * *}$ & $190.6002^{* * *}$ \\
\hline
\end{tabular}

Note: ${ }^{*}$ Significant at $0.1 ;{ }^{* *}$ Significant at $0.05 ;{ }^{* * *}$ Significant at 0.01 . Notes: DY is dividend yield; TAG is total assets growth; SG is sales growth; EPSSP is earning per share to stock price; CI is capital intensiveness; FS is firm size.

and 2013 at the significance level of 0.01. EPSSP as investment opportunity proxy is negatively significant in 2006 (Coef. $=-0.2393, \mathrm{t}=-2.3503$ ) at the significance level of 0.05 and positively significant in 2011 (Coef. $=$ $0.6453, \mathrm{t}=2.8630$ ) at the significance level of 0.01 . The impact of ROA is significant in the period of 2004 through 2008 at the level of 0.1 and in 2010 and 2011 at the level of 0.05 . There is direct relationship between $\mathrm{FL}$ and $\mathrm{CI}$ as the CI is significant in the whole periods at the significance level of 0.01 .

\subsection{Combined Analysis from 2004-2013}

The table mentioned below explains the regression outcomes for the selected set of variables in order to define the Financial Leverage of all banking firms of Pakistan listed in Karachi Stock Exchange from the period of 2004 to 2013.

\section{Regression Analysis}

In order to move for further analysis, the study has considered the major assumptions which are very important in panel data analysis. Table 5 highlights the regression results with two controlling variables.

Table 5 narrates in regression model capital intensiveness (CI) has significant positive relationship with financing decision determined by FL (Coef. $=0.3217, t=5.1243$ ) at the significance level of 0.01 , showing that the banking firms are more capital intensive. There is a negative interaction between the EPSSP (Coef. = $-0.1617, \mathrm{t}=-1.9765$,) and FL at 0.10 level of significance. The negative value of EPSSP indicates investment risk. The effect of firm size (FS) on financial leverage (FL) is significant negative (Coef. $=-0.2118, t=-2.8977$ ) at the significance level of 0.01 . Moreover, a direct correlation between the FL and the profitability of firm measured by ROA (Coef. $=0.4734, t=7.4221$ ) is found at 0.01 level of significance. As for TAG and SG concern, both these variables have negative but insignificant effect on the FL of banking firms as showing (Coef. = 
Table 4. Regression analysis of total debt to total assets using absolute dividend yield (t-value in Parenthesis) (Equation: (4)).

\begin{tabular}{|c|c|c|c|c|c|c|c|c|c|c|}
\hline \multirow{3}{*}{ Variable } & \multicolumn{10}{|c|}{ Panel B } \\
\hline & \multicolumn{10}{|c|}{ Regression analysis with ROA controlling variable } \\
\hline & 2004 & 2005 & 2006 & 2007 & 2008 & 2009 & 2010 & 2011 & 2012 & 2013 \\
\hline \multirow[t]{2}{*}{ Constant } & -0.0431 & $-0.1836^{* *}$ & $0.1357^{* * *}$ & 0.0257 & 0.0006 & $-0.0619^{* * *}$ & -0.0021 & 0.0005 & $0.0058^{* *}$ & -0.0018 \\
\hline & $(-1.6742)$ & $(-2.3168)$ & (5.3576) & $(0.6601)$ & $(0.0582)$ & $(-3.1095)$ & $(-0.0750)$ & $(0.0210)$ & $(2.1249)$ & $(-0.4624)$ \\
\hline \multirow[t]{2}{*}{ DY } & -0.0586 & -0.0544 & $-0.3774^{* * *}$ & -0.5961 & $0.3906^{* * *}$ & -0.4131 & -0.2905 & $-0.5141^{*}$ & -0.0941 & 0.1825 \\
\hline & $(-0.3467)$ & $(-0.4502)$ & $(-3.5505)$ & $(-1.1633)$ & (3.0969) & $(-1.4069)$ & $(-0.8720)$ & $(-1.9844)$ & $(-0.7373)$ & $(0.8638)$ \\
\hline \multirow[t]{2}{*}{ TAG } & -0.0469 & 0.0395 & 0.1259 & -0.0039 & 0.0006 & $-0.4630^{* * *}$ & 0.0202 & -0.0050 & $-0.3413^{* * *}$ & $-0.1604^{* * *}$ \\
\hline & $(-0.5525)$ & $(0.3526)$ & $(1.5260)$ & $(-0.0268)$ & $(0.0124)$ & $(-2.8639)$ & $(0.1333)$ & $(-0.0648)$ & $(-4.9563)$ & $(-3.0233)$ \\
\hline \multirow[t]{2}{*}{ SG } & 0.0833 & 0.0988 & -0.0479 & -0.0899 & 0.0374 & $0.4237^{* * *}$ & -0.1131 & 0.0567 & 0.0031 & $0.1678^{* *}$ \\
\hline & (0.9967) & $(0.8176)$ & $(-0.6131)$ & $(-0.6174)$ & (0.6286) & (3.1760) & $(-0.7736)$ & (0.9111) & $(0.0833)$ & (2.6881) \\
\hline \multirow[t]{2}{*}{ EPSSP } & -0.0083 & -0.0430 & $-0.2393^{* *}$ & 0.0308 & 0.0129 & 0.2773 & 0.4491 & $0.6453^{* * *}$ & 0.1358 & -0.1148 \\
\hline & $(-0.0490)$ & $(-0.3596)$ & $(-2.3503)$ & $(0.0598)$ & $(0.1031)$ & $(0.6124)$ & (1.2758) & (2.8630) & (1.0466) & $(-0.6130)$ \\
\hline \multirow[t]{2}{*}{$\mathrm{CI}$} & $0.4136^{* * *}$ & $0.5206^{* * *}$ & $0.5292^{* * *}$ & $0.6012^{* * *}$ & $0.7507^{* * *}$ & $1.1085^{* * *}$ & $0.7608^{* * *}$ & $0.7951^{* * *}$ & $1.1539^{* * *}$ & $1.0392^{* * *}$ \\
\hline & (6.1628) & (3.5455) & (5.6119) & (3.7479) & (12.4659) & (11.4150) & (8.1698) & (12.0700) & (33.6311) & (30.3811) \\
\hline \multirow[t]{2}{*}{ ROA } & $1.0158^{* * *}$ & $1.0745^{* * *}$ & $0.9391^{* * *}$ & $1.1000^{* * *}$ & $-0.5674^{* * *}$ & -0.1257 & $-0.4002^{* *}$ & $-0.1941^{* *}$ & -0.0694 & -0.0976 \\
\hline & (17.4666) & (9.2542) & (14.2698) & (10.9159) & $(-6.7221)$ & $(-0.5136)$ & $(-2.2838)$ & $(-2.1479)$ & $(-1.2761)$ & $(-1.2721)$ \\
\hline $\mathrm{R}^{2}$ & 0.9753 & 0.8945 & 0.9399 & 0.8985 & 0.9705 & 0.9369 & 0.9307 & 0.9803 & 0.9927 & 0.9872 \\
\hline Adjusted $\mathrm{R}^{2}$ & 0.9569 & 0.8369 & 0.9199 & 0.8580 & 0.9595 & 0.9132 & 0.9047 & 0.9729 & 0.9899 & 0.9824 \\
\hline $\mathrm{F}$ & $52.7418^{* * *}$ & $15.5415^{* * *}$ & $46.9551^{* * *}$ & $22.1399^{* * *}$ & $87.8595^{* * *}$ & $39.5932^{* * *}$ & $35.8237^{* * *}$ & $132.6655^{* * *}$ & $361.8560^{* * * *}$ & $205.6436^{* * *}$ \\
\hline
\end{tabular}

Note: ${ }^{*}$ Significant at $0.1 ;{ }^{* * *}$ Significant at $0.05 ;{ }^{* * *}$ Significant at 0.01 . Notes: DY is dividend yield; TAG is total assets growth; SG is sales growth; EPSSP is earning per share to stock price; $\mathrm{CI}$ is capital intensiveness; ROA is return on assets.

Table 5. Regression results (Equation: (2)).

\begin{tabular}{cccc}
\hline & \multicolumn{2}{c}{ Dependent Variable: Financial Leverage (FL) } & p-value \\
\hline Variables & Coefficient & t-statistics & $0.000211^{* * *}$ \\
\hline (Constant) & 0.575299 & 3.768812 & 0.522710 \\
DY & -0.051996 & -0.640198 & 0.779646 \\
TAG & -0.015036 & -0.280124 & 0.636136 \\
SG & -0.027459 & -0.473767 & $0.049345^{*}$ \\
EPSSP & -0.161715 & -1.976521 & $0.000001^{* * *}$ \\
CI & 0.321783 & 5.124365 & $0.004138^{* * * *}$ \\
FS & -0.211868 & -2.897760 & $0.000000^{* * *}$ \\
ROA & 0.473427 & 7.422158 & \\
R & 0.408636 & & \\
Adjusted R & 0.384444 & & \\
F-statistics & $16.89123^{* * *}$ & & \\
\hline
\end{tabular}

Note: ${ }^{*}$ Sig. at $0.10 ;{ }^{* *}$ Sig. at $0.05 ;{ }^{* * *}$ Sig. at 0.01 .

$-0.0150, \mathrm{t}=-0.2801$ ) and (Coef. $=-0.0274, \mathrm{t}=-0.4737$ ) respectively. The dividend yield (DY) has no impact on firm's financing decision (financial leverage).

\subsection{Discussion}

There is a negative effect of total assets growth on banks financing decision in economic normal (2012, 2013), 
and there is no effect of total assets growth in the period of 2004 to 2011, it can be concluded that there is no impact of total assets growth on financing decision in high uncertainty conditions. The result does not confirm the balancing theory. Other proxy of actual investment, sales growth has inconsistent effect on financing decision. In general, the impact of realized growth on financing decision is less consistent. While in 2009 and 2013, sales growth has statistically significant positive effect on financing decision.

Earnings per share to stock price positively influences financing decision in the less uncertainty conditions (2011) and negatively influences financing decision in high uncertainty conditions (2009, 2010). The results suggest that in less risky conditions, banking firms use higher debt to finance their growth of future. In high risky conditions, banking firms use lesser debt to finance their growth of future. The outcomes are the same as the balancing theory. The impact of earning per share to stock price is sensitive to the controlling variables. Another proxy of investment opportunity, capital intensiveness (total equity to sales) positively influences financing decision in less risky conditions.

The effect of dividend policy on financing decision is insignificant and inconsistent. The sign of coefficient parameter is also not consistent. However, the negative sign of coefficient is not consistent with the prediction of the agency theory. This study tries to describe an empirical evidence outcome on the basis of capital structure theories combination. The assumption of pecking order theory is "dividend is sticky". Any change in the dividend indicates a firm's managers try to convey specific information. Thus, on the basis of this theory, signaling theory indicates that growing (increasing) dividend is good signal (Miller and Rock) [39] and decreasing dividend is bad news.

The negative impact of dividend on the banks financing decision suggests that banking firms reduce debt financing and payment of dividend. When a firm forecasts that there are high risky conditions in the near future, firms decrease the debt financing (balancing theory). Thus, on the basis of three theories combination, it can be concluded that in 2004, firm's managers have forecasted that firm's prospect in the following next years (2005-2009) is bad. Hence, managers of the firms decrease the payment of dividend to convey a bad signal of information to the investors, and to reduce the risk of bankruptcy in the near future high risky conditions, they reduce the debt financing.

While considering the regression results of whole period from 2004 through 2013. From the Table 5, it can be seen that there is an inverse association between actual investment measured in terms of earning per share to stock price (EPSSP) and financing decision. The outcomes are consistent with Fisher separation theorem and Berkovitch and Narayanan [37]. But the outcomes are not consistent with Myers and Majluf [13] and Galeotti and Dieci [36]. The results are also inconsistent with Smirlock and Marshall [40]. Other investment opportunity, capital intensiveness measured in terms of total equity to sales has direct interaction with financing decision. The results are consistent with Myers and Majluf [13] and Galeotti and Dieci [36]. Dividend policy has no impact on financing decision. The outcomes of dividend policy are different with agency theory which predicts that there is a positive impact of dividend policy on financing decision. Moreover, controlling variable firm size has significant negative linkage with financing decision and return on assets has positive relationship with financing decision.

\section{Conclusions}

This study investigates empirically the effect of dividend policy and investment decision on financing decision. To obtain the objectives, the data required, ranging from 2004 to 2013, is collected from the financial statements of all the banking firms listed in Karachi Stock exchange. Two proxies, which are used in this research to represent investment decision, are investment opportunity and actual investment. The effects of profitability and size effect are controlled in this research. Regression analysis is used in this research to estimate the coefficients of interest.

Findings of research do not support the balancing theory which suggests that there should be a positive effect of growth in less risky conditions and negative effect in high risky conditions on financing decision. But there is a negative effect of total assets growth on banks financing decision in economic normal (less uncertainty conditions) and no impact of total assets growth on financing decision is found in high uncertainty conditions. The impact of investment decision on firms financing decision depends on the risk level. The empirical evidence shows that firms use more debt in less risky conditions to finance their investment and use less debt in high risky conditions to finance their investment. The present research shows that investment opportunity (future growth) 
influences financing decision more powerfully than actual investment (realized growth).

Research results also show that no single theory is there that can explain the impact of dividend policy on firms financing decision. This study argues that by the combination of three theories: balancing theory, pecking order theory and signaling theory the impact of dividend policy on financing decision can be explained. But the effect of dividend policy on financing decision is insignificant and inconsistent, which is not consistent with the prediction of the theories.

While considering the regression results of the whole period from 2004 to 2013, research findings show that there is an inverse association between actual investment (EPSSP) and financing decision. Other investment opportunity, capital intensiveness has direct interaction with financing decision. The association between size and financing decision is negative and between return on assets and financing decision is positive.

\subsection{Policy Implications}

The findings of this empirical study are beneficial for bankers and academic researchers. Results are also beneficial for internal and external investors while taking decision of investment in respective capital market. The research might be helpful for the mangers of commercial banks in order to concentrate on the factors which actually determine the financing policy of banks; it will make them able to take more strategic approach to add value in the organization.

\subsection{Limitations and Future Directions}

1) This paper only focuses on the dividend policy and investment decision as determinants of financing decision. Further studies can examine the interdependency among the financial policies. By developing the simultaneous equation model, further studies can develop the model.

2) This study uses only year-by-year data. Hence the future researcher can use the average values of data in order to avoid the discretionary accrual effect, which can be made by the firm's managers.

3) The present research does not use the risk variable, such as beta, variance or standard deviation of return, or any other method in order to measure the risk explicitly. Further studies can include this variable as controlling variable.

\section{References}

[1] Copeland, T.E., Weston, J.F., Shastri, K. and Education, P. (1983) Financial Theory and Corporate Policy (Vol. 3). Addison-Wesley, Massachusetts.

[2] Chen, A.H. (1978) Recent Developments in the Cost of Debt Capital. The Journal of Finance, 33, 863-877. http://dx.doi.org/10.1111/j.1540-6261.1978.tb02027.x

[3] Modigliani, F. and Miller, M.H. (1958) The Cost of Capital, Corporation Finance and the Theory of Investment. The American Economic Review, 48, 261-297.

[4] Miller, M.H. (1977) Debt and Taxes. The Journal of Finance, 32, 261-275.

[5] DeAngelo, H. and Masulis, R.W. (1980) Leverage and Dividend Irrelevancy under Corporate and Personal Taxation. The Journal of Finance, 35, 453-464. http://dx.doi.org/10.1111/j.1540-6261.1980.tb02176.x

[6] Brigham, E.F., Gapenski, L.C. and Dave, P.R. (1999) Intermediate Financial Management. 6th Edition, The Dryden Press, Harcourt Brace College Publisher, Fort Worth, p. 377.

[7] Taggart Jr., R. (1980) Taxes and Corporate Capital Structure of the Firm. Journal of Finance, 35, 119-127. http://dx.doi.org/10.1111/j.1540-6261.1980.tb03474.x

[8] DeAngelo, H. and Masulis, R.W. (1980) Optimal Capital Structure under Corporate and Personal Taxation. Journal of Financial Economics, 8, 3-29. http://dx.doi.org/10.1016/0304-405X(80)90019-7

[9] Gardner, J.C. and Trzcinka, C.A. (1992) All-Equity Firms and the Balancing Theory of Capital Structure. Journal of Financial Research, 15, 77-90. http://dx.doi.org/10.1111/j.1475-6803.1992.tb00788.x

[10] Bayless, M.E. and Diltz, J.D. (1994) Securities Offerings and Capital Structure Theory. Journal of Business Finance \& Accounting, 21, 77-91. http://dx.doi.org/10.1111/j.1468-5957.1994.tb00306.x

[11] Jensen, M.C. and Meckling, W.H. (1979) Theory of the Firm: Managerial Behavior, Agency Costs, and Ownership Structure. Springer, Dordrecht.

[12] Myers, S.C. (1984) The Capital Structure Puzzle. The Journal of Finance, 39, 574-592. 
http://dx.doi.org/10.1111/j.1540-6261.1984.tb03646.x

[13] Myers, S.C. and Majluf, N.S. (1984) Corporate Financing and Investment Decisions When Firms Have Information That Investors Do Not Have. Journal of Financial Economics, 13, 187-221. http://dx.doi.org/10.1016/0304-405X(84)90023-0

[14] Brigham, E.F., Gapenski, L.C. and Dave, P.R. (1999) Intermediate Financial Management. 6th Edition, The Dryden Press, Harcourt Brace College Publisher, Fort Worth, p. 376.

[15] Megginson, W.L., Megginson, D. and Meggison, W. (1997) Corporate Finance Theory. Addison-Wesley, Reading.

[16] Crutchley, C.E. and Hansen, R.S. (1989) A Test of the Agency Theory of Managerial Ownership, Corporate Leverage, and Corporate Dividends. Financial Management, 18, 36-46. http://dx.doi.org/10.2307/3665795

[17] Kale, J.R., Noe, T.H. and Ramirez, G.G. (1991) The Effect of Business Risk on Corporate Capital Structure: Theory and Evidence. The Journal of Finance, 46, 1693-1715. http://dx.doi.org/10.1111/j.1540-6261.1991.tb04640.x

[18] Carleton, W.T. and Silberman, I.H. (1977) Joint Determination of Rate of Return and Capital Structure: An Econometric Analysis. The Journal of Finance, 32, 811-821. http://dx.doi.org/10.1111/j.1540-6261.1977.tb01990.x

[19] Baskin, J. (1989) An Empirical Investigation of the Pecking Order Hypothesis. Financial Management, 18, $26-35$. http://dx.doi.org/10.2307/3665695

[20] Barton, S.L., Hill, N.C. and Sundaram, S. (1989) An Empirical Test of Stakeholder Theory Predictions of Capital Structure. Financial Management, 18, 36-44. http://dx.doi.org/10.2307/3665696

[21] Adedeji, A. (1998) Does the Pecking Order Hypothesis Explain the Dividend Payout Ratios of Firms in the UK? Journal of Business Finance \& Accounting, 25, 1127-1155. http://dx.doi.org/10.1111/1468-5957.00230

[22] Shyam-Sunder, L. and Myers, S.C. (1999) Testing Static Tradeoff against Pecking Order Models of Capital Structure. Journal of Financial Economics, 51, 219-244. http://dx.doi.org/10.1016/S0304-405X(98)00051-8

[23] Jensen, G.R., Solberg, D.P. and Zorn, T.S. (1992) Simultaneous Determination of Insider Ownership, Debt, and Dividend Policies. Journal of Financial and Quantitative Analysis, 27, 247-263. http://dx.doi.org/10.2307/2331370

[24] Griner, E.H. and Gordon, L.A. (1995) Internal Cash Flow, Insider Ownership, and Capital Expenditures: A Test of the Pecking Order and Managerial Hypotheses. Journal of Business Finance \& Accounting, 22, 179-199. http://dx.doi.org/10.1111/j.1468-5957.1995.tb00678.x

[25] Brigham, E.F., Gapenski, L.C. and Dave, P.R. (1999) Intermediate Financial Management. 6th Edition, The Dryden Press, Harcourt Brace College Publisher, Fort Worth, p. 327.

[26] Kalay, A. (1982) Stockholder-Bondholder Conflict and Dividend Constraints. Journal of Financial Economics, 10, 211-233. http://dx.doi.org/10.1016/0304-405X(82)90014-9

[27] Harris, M. and Raviv, A. (1990) Capital Structure and the Informational Role of Debt. The Journal of Finance, 45, 321-349. http://dx.doi.org/10.1111/j.1540-6261.1990.tb03693.x

[28] Easterbrook, F.H. (1984) Two Agency-Cost Explanations of Dividends. The American Economic Review, 74, 650-659.

[29] Myers, S.C. (1977) Determinants of Corporate Borrowing. Journal of Financial Economics, 5, 147-175. http://dx.doi.org/10.1016/0304-405X(77)90015-0

[30] Gaver, J.J. and Gaver, K.M. (1993) Additional Evidence on the Association between the Investment Opportunity Set and Corporate Financing, Dividend, and Compensation Policies. Journal of Accounting and Economics, 16, 125-160. http://dx.doi.org/10.1016/0165-4101(93)90007-3

[31] Smith Jr., C.W. and Watts, R.L. (1992) The Investment Opportunity Set and Corporate Financing, Dividend, and Compensation Policies. Journal of Financial Economics, 32, 263-292. http://dx.doi.org/10.1016/0304-405X(92)90029-W

[32] Kallapur, S. and Trombley, M.A. (1999) The Association between Investment Opportunity Set Proxies and Realized Growth. Journal of Business Finance \& Accounting, 26, 505-519. http://dx.doi.org/10.1111/1468-5957.00265

[33] Wang, C.-P., Huang, H.-H. and Wang, D.-Y. (2010) Investment, Dividend, Debt Decisions and Business Life Cycle. Journal of Statistics and Management Systems, 13, 1305-1321. http://dx.doi.org/10.1080/09720510.2010.10701535

[34] Kaaro, H. (2002) Investment Decision and Dividend Policy as Determinants of Financing Decision. Journal of Accounting, Management and Economic Research, 2, 41-55.

[35] Abbott, L.J. (2001) Financing, Dividend and Compensation Policies Subsequent to a Shift in the Investment Opportunity Set. Managerial Finance, 27, 31-47. http://dx.doi.org/10.1108/03074350110767088

[36] Galeotti, M. and Dieci, R. (2000) A Model of Optimal Financing Decisions in a Stochastic Framework. Journal of Statistics and Management Systems, 3, 43-66. http://dx.doi.org/10.1080/09720510.2000.10701005

[37] Berkovitch, E. and Narayanan, M. (1993) Timing of Investment and Financing Decisions in Imperfectly Competitive Financial Markets. Journal of Business, 66, 219-248. http://dx.doi.org/10.1086/296602 
[38] Healy, P.M. (1985) The Effect of Bonus Schemes on Accounting Decisions. Journal of Accounting and Economics, 7, 85-107. http://dx.doi.org/10.1016/0165-4101(85)90029-1

[39] Miller, M.H. and Rock, K. (1985) Dividend Policy under Asymmetric Information. The Journal of Finance, 40, 10311051. http://dx.doi.org/10.1111/j.1540-6261.1985.tb02362.x

[40] Smirlock, M. and Marshall, W. (1983) An Examination of the Empirical Relationship between the Dividend and Investment Decisions: A Note. The Journal of Finance, 38, 1659-1667.

http://dx.doi.org/10.1111/j.1540-6261.1983.tb03849.x 